\title{
A qualitative study of old patients' experiences of the quality of the health services in hospital and 30 days after hospitalization
}

\author{
Ingvild Lilleheie ${ }^{1 *}$, Jonas Debesay ${ }^{2}$, Asta Bye $^{3,4}$ and Astrid Bergland ${ }^{4}$
}

\begin{abstract}
Background: The number of people aged 80 years and above is projected to triple over the next 30 years. People in this age group normally have at least two chronic conditions. The impact of multimorbidity is often significantly greater than expected from the sum of the effects of each condition. The World Health Organization has indicated that healthcare systems must prepare for a change in the focus of clinical care for older people. The World Health Organization (WHO) defines healthcare quality as care that is effective, efficient, integrated, patient centered, equitable and safe. The degree to which healthcare quality can be defined as acceptable is determined by services' ability to meet the needs of users and adapt to patients' expectations and perceptions.

Method: We took a phenomenological perspective to explore older patients' subjective experiences and conducted semistructured individual interviews. Eighteen patients (aged from 82 to 100 years) were interviewed twice after discharge from hospital. The interview transcriptions were analyzed thematically.

Results: The patients found their meetings with the health service to be complex and demanding. They reported attempting to restore a sense of security and meaning in everyday life, balancing their own needs against external requirements. Five overarching themes emerged from the interviews: hospital stay and the person behind the diagnosis, poor communication and coordination, life after discharge, relationship with their next of kin, and organizational and systemic determinants.

Conclusion: According to the WHO, to deliver quality healthcare, services must include all six of the dimensions listed above. Our findings show that they do not. Healthcare focused on measurable values and biomedical inquiries. Few opportunities for participation, scant information and suboptimal care coordination left the patients with a feeling of being in limbo, where they struggled to find balance in their everyday life. Further work must be done to ensure that integrated services are provided without a financial burden, centered on the needs and rights of older people.
\end{abstract}

Keywords: Healthcare, Elderly, Quality of care, Patient-centered

\footnotetext{
* Correspondence: Ingvild.Lilleheie@Oslomet.no

'Department of Physiotherapy, Faculty of Health Sciences, Oslo Metropolitan University, Oslo, Norway

Full list of author information is available at the end of the article
}

(c) The Author(s). 2020 Open Access This article is licensed under a Creative Commons Attribution 4.0 International License, which permits use, sharing, adaptation, distribution and reproduction in any medium or format, as long as you give appropriate credit to the original author(s) and the source, provide a link to the Creative Commons licence, and indicate if changes were made. The images or other third party material in this article are included in the article's Creative Commons licence, unless indicated otherwise in a credit line to the material. If material is not included in the article's Creative Commons licence and your intended use is not permitted by statutory regulation or exceeds the permitted use, you will need to obtain permission directly from the copyright holder. To view a copy of this licence, visit http://creativecommons.org/licenses/by/4.0/ The Creative Commons Public Domain Dedication waiver (http://creativecommons.org/publicdomain/zero/1.0/) applies to the data made available in this article, unless otherwise stated in a credit line to the data. 


\section{Background}

According to the United Nations (UN), the number of people aged 80 and above is projected to triple over the next 30 years [1]. The norm in this age group is that people have at least two chronic conditions (multimorbidity) [2]. The impact of multimorbidity on an older person's capacity, healthcare utilization and their costs of care is often significantly greater than might be expected from the sum of the effects of each condition. Therefore, the World Health Organization's (WHO) World Report on Aging and Health [3] urges healthcare systems to prepare for a fundamental change in the focus of clinical care for older people. In recent years, most Western countries have transferred responsibility for tasks previously carried out in hospitals to municipalities. The result of this policy is decreased hospitalization time in all OECD (Organisation for Economic Co-operation and Development) countries [4]. As the average length of stay declines, two consequences have appeared: elderly people are discharged from the hospital "quicker and sicker" than previously $[5,6]$, and the healthcare provider has less time to coordinate services across settings and to prepare the patients for the home situation [7]. The WHO defines healthcare quality as care that is effective, efficient, integrated, patient centered, equitable and safe [8]. The degree to which healthcare quality can be defined as acceptable is strongly dependent on service providers' ability to meet the needs of their users [9] and adapt to patients' expectations and perceptions [10].

The concept of patient centeredness and patient participation is defined as "a patient's rights and opportunities to influence and engage in the decision making about his care through a dialogue attuned to his preferences, potential and a combination of his experiential and the professional's expert knowledge" [11]. Successful patient participation is associated with satisfaction with healthcare services [12], better treatment outcomes [13], shorter institutional stays [14] and fewer readmissions [15]. The transition between levels of the healthcare system and the period subsequent to hospital discharge is critical for elderly patients $[16,17]$. Therefore, readmissions within 30 days after hospital discharge, referred to as " 30 -day rehospitalizations," are frequent adverse outcomes for this population $[18,19]$ with deleterious consequences, including loss of autonomy, increased mortality $[20,21]$ and high socioeconomic costs $[22,23]$. All factors related to health quality based on the WHO definition.

The key challenge in achieving good quality healthcare for older patients is to adapt it to the needs of older people-as perceived by themselves. The patients' perspective on their care journey between levels of the healthcare system may provide valuable information to guide quality improvement in health services [24]. To the best of our knowledge, no previous study has investigated the experiences of older patients above the age of 80 years of the quality of healthcare in hospital and the critical period after hospitalization. Thus, this study explores their experiences of the quality of the health services in hospital and the first 30 days at home after discharge. Our findings may enhance understanding of older patients' experiences of adapting to daily life at home after discharge. By exploring the underlying mechanisms through the lens of healthcare quality and patient-centered care, we hope to provide useful information to reduce the gap between policy and clinical work in healthcare for older people.

\section{Methods}

This study was part of a larger project addressing crosssectoral care transitions for older patients from specialized hospital care to municipal health and care services, including the first 30 days after discharge [25]. The first period following hospital discharge is a vulnerable time for patients [24], and their journey between healthcare sectors may provide important information that can be used to improve the quality of transitional care.

\section{Design}

Based on a qualitative design we used a phenomenological perspective to explore and describe older patients' subjective experiences [26]. We sought to understand the complexity of the participants' view of their situation, and our goal was to rely as much as possible on their perspectives.

\section{Setting and participants}

In Norway, healthcare is mainly state funded and accessible to all inhabitants. Hospitals are primarily responsible for acute and specialized healthcare services, and the municipalities provide healthcare suitable for early identification and follow up of somatic and mental health [27]. Home care services in Norway are administered by the municipality for people who require healthcare services for long or short periods as a result of illness, impaired health, old age or other factors [28].

We recruited a purposive sample of participants [29] from an acute geriatric ward at a large hospital in Norway. Acute geriatric wards are defined as wards with an independent physical location and structure run by a specialized multidisciplinary team with direct responsibility for the care of older people with acute medical disorders [30]. Patients unable to give informed consent were not included in the study. The inclusion criteria were that patients had to be aged 80 years or above, living at home prior to hospitalization and were to be transferred to one of the following services: short-term stay at a nursing home (intermediate care) or own home with health services from the municipality. The health 
professionals at the hospital ward identified patients who fulfilled the inclusion criteria. Twenty-two patients agreed to participate and 18 were interviewed after discharge from hospital. The reasons for subject dropout included patients who were readmitted to hospital before the interview $(n=3)$ or changed their mind about participation $(n=1)$. To describe the functional and mental characteristics of the participants (see Table 1), we conducted the 30s Chair Stand Test (CST). The 30s CST is a functional evaluation clinical test that measures lower body strength, which is related to demanding activities in daily life [31, 32]. The test can predict health status, survival and hospital costs [33]. In addition, we performed the Mini Mental State Examination (MMSE) to assess cognitive function [34].

Participants ranged in age from 82 to 100 years old, with a mean age of 92 years. The characteristics of the patients are shown in Table 1.

\section{Data collection}

Data collection took place between September 2017 and March 2018. A semistructured interview guide with open-ended questions was developed. The questions were based on established standards for quality in healthcare [8] (see Table 2). To refine the questions, two pilot interviews were conducted. The interviews were conducted one-on-one 1-2 weeks after discharge at each patient's current residence. To capture their recent experiences from the actual transition and to obtain information about their experiences from the whole 30-day period, a follow-up interview was conducted approximately 30 days after discharge. Three participants were only interviewed once owing to their health status at the time of the second interview. The interviews lasted from $30 \mathrm{~min}$ to $115 \mathrm{~min}$, and were performed by the first author of this article, who is an experienced physical therapist with long experience working with elderly patients. The interviewer was not involved in the treatment of the patients in the study. All interviews were audiotaped and transcribed verbatim by a professional transcriber. Participant names and other personal identifiers were removed from the transcripts.

In qualitative studies, $15 \pm 10$ participants is considered to be a sufficient sample size to obtain information about the research phenomena with a manageable amount of data [35]. We aimed to recruit 20 patients or to continue recruitment until we reached data saturation [29].

\section{Data analysis}

We analyzed the data using thematic analysis [36, 37], a method for identifying, analyzing and reporting patterns in qualitative data. Rather than starting with a theory, we inductively developed patterns of meaning through thematic analysis [38].
To ensure consistency of data analysis, we adopted the six-phase approach to thematic analysis described by Braun and Clarke [36]. This approach has been widely used and accepted as robust across a wide range of disciplines, including human health research [39]. To maximize trustworthiness and limit threats to validity, we employed the criterion for 'trustworthiness' outlined by Lincoln and Guba (1985) [40]. We satisfied the criterion of credibility through open-ended questioning, prolonged engagement with the data and by providing a detailed description of the methods. We fulfilled the criterion of transferability by presenting detailed and indepth descriptive data and by quoting the participants. To satisfy the criterion of dependability, reiterative reading of the transcripts by two of the authors (I. L. and A. B.) was performed to transform the ideas generated into a set of codes to identify the interesting features of the data. These initial codes were then categorized into potential themes. The themes were discussed and reviewed by all authors to reflect on their relevance to the research questions [41]. All the authors who performed the analysis were educated in the health fields of physiotherapy (two), nursing (one) or nutrition (one), and have extensive research and/or clinical experience in the field of elder healthcare. The themes were then refined to ensure that each was meaningful and clear but distinct from other themes [42]. See Table 3 for an example of the coding strategy. In addition, we followed the consolidated criteria for reporting qualitative studies (COREQ) [43] (see the Supplementary File).

\section{Ethical considerations}

The study was preapproved and registered by the Norwegian Center for Research Data (No. 53110). All of the patients were deemed able to give informed consent by healthcare personnel in hospital. The first author approached the participants in hospital, and provided them with verbal and written information outlining the purpose of the study. We informed them that participation was voluntary and about their right to withdraw from the study at any stage. We assured them that this would not affect their current or future access to services. We obtained written and informed consent from all participants and guaranteed their confidentiality.

\section{Results}

Our findings illustrate that the patients found their encounters with the health service to be complex and demanding. They reported that after discharge, they attempted to restore a sense of security and meaning to everyday life, balancing their own needs against external requirements, such as organizational and political demands. Below, we will present our findings in terms of five overarching and interrelated themes emerging from the interviews. 
Table 1 Patient characteristics

\begin{tabular}{|c|c|c|c|c|c|c|c|c|c|c|c|}
\hline No & Age & Gender & $\begin{array}{l}\text { Hospital } \\
\text { days }\end{array}$ & $\begin{array}{l}\text { Intermed. } \\
\text { care unit } \\
\text { Y/N }\end{array}$ & Medical diagnosis & $\begin{array}{l}\text { Medication } \\
\text { at discharge }\end{array}$ & 30 s sit-to-stand & MMSE $^{1}$ & $\begin{array}{l}\text { Life } \\
\text { situation }\end{array}$ & $\begin{array}{l}\text { Next of } \\
\text { kin }\end{array}$ & $\begin{array}{l}\text { No. of } \\
\text { inter- } \\
\text { views }\end{array}$ \\
\hline $\mathrm{P1}$ & 95 & $\mathrm{~F}$ & 8 & Y & $\begin{array}{l}\text { Pyelonephritis } \\
\text { Sepsis } \\
\text { Dehydration } \\
\text { Kidney failure } \\
\text { Hypertension } \\
\text { Hypoalbuminemia } \\
\text { Malnutrition }\end{array}$ & $\begin{array}{l}\text { Esomeprazol } \\
\text { Calcigran } \\
\text { forte } \\
\text { Lactulose } \\
\text { Zopiclone } \\
\text { Omega } 3 \\
\text { Selo Zok } \\
\text { Amlodipine } \\
\text { Multivitamin } \\
\text { Ciproxin }\end{array}$ & 6 & 29 & Alone & Daughter & 2 \\
\hline P2 & 90 & $\mathrm{~F}$ & 10 & Y & $\begin{array}{l}\text { Acute cystitis } \\
\text { E. coli infection } \\
\text { Orthostatic } \\
\text { hypotension } \\
\text { Hypertension } \\
\text { Contusion lower } \\
\text { back } \\
\text { Anxiety } \\
\text { Constipation }\end{array}$ & $\begin{array}{l}\text { Albyl E } \\
\text { Esomeprazol } \\
\text { Lescol } \\
\text { Levaxin }\end{array}$ & $\begin{array}{l}\text { Not able to } \\
\text { perform owing } \\
\text { to physical } \\
\text { condition }\end{array}$ & 19 & Alone & Daughter & 2 \\
\hline P3 & 88 & $\mathrm{~F}$ & 6 & N & $\begin{array}{l}\text { Pneumonia } \\
\text { Aortic stenosis } \\
\text { Hypertension } \\
\text { Folic acid } \\
\text { deficiency }\end{array}$ & $\begin{array}{l}\text { Candesartan } \\
\text { Albyl E, } \\
\text { Simvastatin } \\
\text { Taflotan eye } \\
\text { drops } \\
\text { Folic acid } \\
\text { Apocillin }\end{array}$ & 8 & 29 & $\begin{array}{l}\text { With } \\
\text { spouse }\end{array}$ & Sister & 2 \\
\hline P5 & 96 & $\mathrm{~F}$ & 7 & N & $\begin{array}{l}\text { Heart failure } \\
\text { Hypertension }\end{array}$ & $\begin{array}{l}\text { Selo Zok } \\
\text { Triatec } \\
\text { Burinex } \\
\text { Somac }\end{array}$ & $\begin{array}{l}\text { Not able to } \\
\text { perform owing } \\
\text { to physical } \\
\text { condition }\end{array}$ & 25 & Alone & Daughter & 2 \\
\hline P6 & 95 & $\mathrm{~F}$ & 8 & N & $\begin{array}{l}\text { Heart failure } \\
\text { Cognitive failure } \\
\text { Biological aortic } \\
\text { valve } \\
\text { Malnutrition }\end{array}$ & $\begin{array}{l}\text { Burinex } \\
\text { Renitec } \\
\text { Spirix } \\
\text { Metoprolol } \\
\text { depot } \\
\text { Calcigran } \\
\text { forte } \\
\text { Loratadine } \\
\text { Prolia } \\
\text { Imovane } \\
\text { Paracetamol } \\
\text { Triobet } \\
\text { Warfarin }\end{array}$ & 4 & 25 & Alone & $\begin{array}{l}\text { Grand } \\
\text { daughter }\end{array}$ & 2 \\
\hline P7 & 98 & M & 7 & N & $\begin{array}{l}\text { Acute respiratory } \\
\text { tract infection } \\
\text { Tumor bladder } \\
\text { Hydronephrosis } \\
\text { Acute renal failure } \\
\text { Acidosis }\end{array}$ & $\begin{array}{l}\text { Albyl E } \\
\text { Burinex } \\
\text { Cipralex } \\
\text { Remeron } \\
\text { Monoket } \\
\text { Natron } \\
\text { Multivitamins } \\
\text { Omeprazole } \\
\text { Imovane } \\
\text { Enaton }\end{array}$ & 1 & 27 & Alone & Daughter & 2 \\
\hline P8 & 96 & $\mathrm{~F}$ & 5 & N & $\begin{array}{l}\text { Aortic stenosis } \\
\text { Orthostatic } \\
\text { hypotension } \\
\text { Pulmonary } \\
\text { hypertension }\end{array}$ & $\begin{array}{l}\text { Azopt } \\
\text { eyedrops, } \\
\text { Selexid }\end{array}$ & 7 & 28 & Alone & Daughter & 2 \\
\hline P9 & 97 & $\mathrm{~F}$ & 7 & Y & $\begin{array}{l}\text { Orthostatic } \\
\text { hypotension } \\
\text { Concussion } \\
\text { Rib fracture }\end{array}$ & $\begin{array}{l}\text { Albyl E } \\
\text { Zanidip } \\
\text { Paracetamol } \\
\text { Lactulose }\end{array}$ & $\begin{array}{l}\text { Not able to } \\
\text { perform owing } \\
\text { to physical } \\
\text { condition }\end{array}$ & 24 & Alone & Son & 2 \\
\hline
\end{tabular}


Table 1 Patient characteristics (Continued)

\begin{tabular}{|c|c|c|c|c|c|c|c|c|c|c|c|}
\hline $\mathrm{No}$ & Age & Gender & $\begin{array}{l}\text { Hospital } \\
\text { days }\end{array}$ & $\begin{array}{l}\text { Intermed. } \\
\text { care unit } \\
\mathrm{Y} / \mathrm{N}\end{array}$ & Medical diagnosis & $\begin{array}{l}\text { Medication } \\
\text { at discharge }\end{array}$ & 30 s sit-to-stand & MMSE $^{1}$ & $\begin{array}{l}\text { Life } \\
\text { situation }\end{array}$ & $\begin{array}{l}\text { Next of } \\
\text { kin }\end{array}$ & $\begin{array}{l}\text { No. of } \\
\text { inter- } \\
\text { views }\end{array}$ \\
\hline & & & & & & $\begin{array}{l}\text { Folic acid } \\
\text { Laxoberal } \\
\text { Nobligan }\end{array}$ & & & & & \\
\hline P10 & 87 & $\mathrm{~F}$ & 7 & N & $\begin{array}{l}\text { Sepsis } \\
\text { Kidney failure } \\
\text { Acute } \\
\text { tubulointerstitial } \\
\text { nephritis }\end{array}$ & $\begin{array}{l}\text { Albyl E } \\
\text { Paracetamol } \\
\text { Selo Zok } \\
\text { Hiprex } \\
\text { Amlodipine } \\
\text { Levaxin } \\
\text { Somac } \\
\text { Ciproxin }\end{array}$ & $\begin{array}{l}\text { One interview (test } \\
\text { taken in second } \\
\text { interview) }\end{array}$ & $\begin{array}{l}\text { One interview } \\
\text { (test taken in } \\
\text { second interview) }\end{array}$ & Alone & Niece & 1 \\
\hline P11 & 82 & M & 5 & N & $\begin{array}{l}\text { Nonspecific jaw } \\
\text { disease } \\
\text { Acute kidney } \\
\text { failure } \\
\text { Magnesium } \\
\text { deficiency } \\
\text { Anemia } \\
\text { Ulcerative colitis }\end{array}$ & $\begin{array}{l}\text { Bicalutamide } \\
\text { Folic acid } \\
\text { Nexium } \\
\text { Prednisolone } \\
\text { Ursofalk } \\
\text { Imovane } \\
\text { Magnesium }\end{array}$ & 4 & 27 & $\begin{array}{l}\text { With } \\
\text { spouse }\end{array}$ & Wife & 2 \\
\hline P13 & 91 & $\mathrm{~F}$ & 5 & N & $\begin{array}{l}\text { Chronic atrial } \\
\text { fibrillation } \\
\text { Stokes-Adams } \\
\text { syndrome } \\
\text { Vitamin D } \\
\text { deficiency }\end{array}$ & $\begin{array}{l}\text { Bisoprolol } \\
\text { Digoxin } \\
\text { Eliquis } \\
\text { Montelukast } \\
\text { Ventolin } \\
\text { Atrovent } \\
\text { Vitamin D } \\
\text { Symbicort, } \\
\text { Ventolin }\end{array}$ & $\begin{array}{l}\text { One interview (test } \\
\text { taken in second } \\
\text { interview) }\end{array}$ & $\begin{array}{l}\text { One interview } \\
\text { (test taken in } \\
\text { second interview) }\end{array}$ & Alone & Niece & 1 \\
\hline P15 & 86 & $\mathrm{~F}$ & 11 & N & $\begin{array}{l}\text { Acute } \\
\text { tubulointerstitial } \\
\text { nephritis } \\
\text { Drop foot } \\
\text { Kidney stones } \\
\text { Degeneration of } \\
\text { macula and } \\
\text { posterior pole }\end{array}$ & $\begin{array}{l}\text { Omeprazol } \\
\text { Calcigran } \\
\text { Taflotan } \\
\text { Timosan } \\
\text { Trusopt } \\
\text { Hiprex } \\
\text { Folic acid } \\
\text { Albyl E } \\
\text { Ciproxin }\end{array}$ & 9 & 30 & Alone & Daughter & 2 \\
\hline P16 & 89 & $\mathrm{~F}$ & 6 & N & $\begin{array}{l}\text { Syncope and } \\
\text { collapse } \\
\text { Acute cystitis } \\
\text { Orthostatic } \\
\text { hypotension }\end{array}$ & $\begin{array}{l}\text { Vagifem } \\
\text { Florinef } \\
\text { Calcigran } \\
\text { forte } \\
\text { Plavix } \\
\text { Lipitor } \\
\text { Cortison } \\
\text { Paracetamol }\end{array}$ & $\begin{array}{l}\text { Not able to perform } \\
\text { owing to physical } \\
\text { condition }\end{array}$ & $\begin{array}{l}\text { Not able to } \\
\text { take test at } \\
\text { the time of } \\
\text { interview }\end{array}$ & Alone & Neighbor & 2 \\
\hline P19 & 82 & $\mathrm{~F}$ & 7 & $N$ & $\begin{array}{l}\text { Gout } \\
\text { Congestive heart } \\
\text { failure } \\
\text { Spinal stenosis } \\
\text { Chronic atrial } \\
\text { fibrillation }\end{array}$ & $\begin{array}{l}\text { Burinex } \\
\text { Xarelto } \\
\text { Letrozole } \\
\text { Levaxin } \\
\text { Nexium } \\
\text { Seretide } \\
\text { Paralgin forte } \\
\text { Paracetamol } \\
\text { Movicol } \\
\text { Colchicine } \\
\text { DauAllopur }\end{array}$ & $\begin{array}{l}\text { Not able to perform } \\
\text { owing to physical } \\
\text { condition }\end{array}$ & 30 & $\begin{array}{l}\text { With } \\
\text { spouse }\end{array}$ & Daughter & 2 \\
\hline $\mathrm{P} 20$ & 86 & M & 6 & N & $\begin{array}{l}\text { Benign } \\
\text { paroxysmal } \\
\text { vertigo } \\
\text { Unspecified } \\
\text { thrombocytopenia }\end{array}$ & $\begin{array}{l}\text { Losec } \\
\text { Albyl E } \\
\text { Triobe }\end{array}$ & 10 & 30 & Alone & Son & 2 \\
\hline P21 & 100 & $\mathrm{~F}$ & 6 & N & Streptococcal & Adalat oros & One interview (test & One interview & Alone & Son & 1 \\
\hline
\end{tabular}


Table 1 Patient characteristics (Continued)

\begin{tabular}{|c|c|c|c|c|c|c|c|c|c|c|c|}
\hline No & Age & Gender & $\begin{array}{l}\text { Hospital } \\
\text { days }\end{array}$ & $\begin{array}{l}\text { Intermed. } \\
\text { care unit } \\
\text { Y/N }\end{array}$ & Medical diagnosis & $\begin{array}{l}\text { Medication } \\
\text { at discharge }\end{array}$ & 30 s sit-to-stand & MMSE $^{1}$ & $\begin{array}{l}\text { Life } \\
\text { situation }\end{array}$ & $\begin{array}{l}\text { Next of } \\
\text { kin }\end{array}$ & $\begin{array}{l}\text { No. of } \\
\text { inter- } \\
\text { views }\end{array}$ \\
\hline & & & & & $\begin{array}{l}\text { sepsis } \\
\text { Erysipelas } \\
\text { Kidney failure }\end{array}$ & $\begin{array}{l}\text { Ovesterin } \\
\text { Bisoprolol } \\
\text { Calcigran } \\
\text { forte } \\
\text { Albyl E } \\
\text { Lamictal } \\
\text { Ery-max }\end{array}$ & $\begin{array}{l}\text { taken in second } \\
\text { interview) }\end{array}$ & $\begin{array}{l}\text { (test taken in } \\
\text { second } \\
\text { interview) }\end{array}$ & & & \\
\hline P22 & 88 & $\mathrm{~F}$ & 7 & N & $\begin{array}{l}\text { Sick sinus } \\
\text { syndrome } \\
\text { Syncope and } \\
\text { collapse }\end{array}$ & $\begin{array}{l}\text { Calcigran } \\
\text { forte } \\
\text { Albyl E } \\
\text { Targinact } \\
\text { Imovane } \\
\text { Hylo gel } \\
\text { Triobet } \\
\text { Paracetamol }\end{array}$ & $\begin{array}{l}\text { Last interview was by } \\
\text { telephone (test taken } \\
\text { in second interview) }\end{array}$ & $\begin{array}{l}\text { Last interview } \\
\text { was by telephone } \\
\text { (test taken in } \\
\text { second interview) }\end{array}$ & Alone & $\begin{array}{l}\text { Support } \\
\text { person }\end{array}$ & 2 \\
\hline P23 & 96 & $\mathrm{~F}$ & 15 & Y & $\begin{array}{l}\text { Pneumonia } \\
\text { Unspecified pelvic } \\
\text { and abdominal } \\
\text { pain } \\
\text { Obstipation } \\
\text { Acute heart attack } \\
\text { Atrial fibrillation } \\
\text { and atrial flutter }\end{array}$ & $\begin{array}{l}\text { Lercanidipine } \\
\text { Albyl E } \\
\text { Pursennid } \\
\text { Pantoprazole } \\
\text { Selo Zok } \\
\text { Eliquis } \\
\text { Prednisolone } \\
\text { Bronkyl loss. }\end{array}$ & 4 & 27 & Alone & $\begin{array}{l}\text { Grand } \\
\text { daughter }\end{array}$ & 2 \\
\hline
\end{tabular}

Mini Mental State Examination (MMSE) to assess cognitive function 34. Tombaugh TN, Mclntyre NJJJotAGS: The mini-mental state examination: a comprehensive review. 1992, 40(9):922-935

\section{Hospital stay and the person behind the diagnosis}

The patients found the hospital to be a pleasant break where they felt safe and free from personal concerns. Most of the patients described the health personnel in the hospital as "compassionate" (P8), "helpful" (P22), "respectful" (P20) and "nice" (P5). Some of the patients had the opportunity to participate in and describe their subjective experiences of their illness: "Yes, I was welcomed and listened to. I was a bit impressed by that" (P8). Despite such experiences, most of the patients reported not feeling encouraged to be involved in collaborative decision-making, and not being asked about their preferences or needs. When questioned about whether the health personnel at the hospital had asked for their

Table 2 Interview guide

1 Describe your situation right now.

2 Describe your experience of the hospital stay.

a. Describe whether anyone at the hospital asked you what mattered most to you from your point of view.

b. Describe your experience of the cooperation/coordination between the healthcare personnel at the hospital.

3 Describe the discharge process as you experienced it.

a. Describe how/when you were informed about discharge.

b. Describe the information you received about/during the discharge process.

c. Describe whether any of the healthcare professionals asked you about your preferences regarding the discharge process.

d. Describe whether your wishes regarding discharge were taken into account.

4 Describe your experience of the transfer between hospital and the healthcare services in the municipality.

5 Describe your experience of the cooperation/coordination between the personnel at the hospital and those in the healthcare services in municipality care.

6 Describe your experience of the information transfer between hospital and municipality.

7 Describe the time after discharge.

8 Describe your experience of the cooperation/coordination between the healthcare personnel in the municipality

a. Describe your experience of the cooperation between your GP and other healthcare personnel in the municipality.

9 Describe whether any of the healthcare professionals in the municipality asked you what mattered most to you from your point of view.

10 (If rehospitalization is a theme: Describe the rehospitalization process.)

11 Looking back, is there anything that should have been done differently regarding the healthcare you have received? 
Table 3 Examples of coding strategy

\begin{tabular}{|c|c|c|c|}
\hline Quotation & Initial code & Subtheme & Theme \\
\hline $\begin{array}{l}\text { The hospital stay was lovely. I enjoyed it, I must say. I basically } \\
\text { have nothing to put my finger on when it comes to nursing and } \\
\text { care and such. I must say I was really happy with that stay, to } \\
\text { come to a place where I could relax. (P3) }\end{array}$ & $\begin{array}{l}\text { The hospital stay was pleasant } \\
\text { and a break from personal } \\
\text { worries }\end{array}$ & $\begin{array}{l}\text { The hospital as a place free } \\
\text { from daily worries }\end{array}$ & $\begin{array}{l}\text { Hospital stay and the } \\
\text { person behind the } \\
\text { diagnosis }\end{array}$ \\
\hline $\begin{array}{l}\text { Then they took samples both here and there, and all kinds of } \\
\text { examinations. And the next day it was the same lesson again } \\
\text { with some blood tests. (P6) }\end{array}$ & $\begin{array}{l}\text { Many blood tests and } \\
\text { different examinations }\end{array}$ & Biomedical approach & \\
\hline $\begin{array}{l}\text { Yes, they told me in the morning because I hadn't been told } \\
\text { before. Therefore, I first thought that there would be no discharge } \\
\text { that day either. But then they came and said, "You're leaving } \\
\text { now. You've got a room." "Yes, well," I just said then. (P23) }\end{array}$ & $\begin{array}{l}\text { I was not informed of } \\
\text { discharge }\end{array}$ & Scant information & $\begin{array}{l}\text { Poor communication } \\
\text { and coordination }\end{array}$ \\
\hline $\begin{array}{l}\text { I have no information about what is going on. No idea. I do not } \\
\text { think there has been any cooperation between the hospital and } \\
\text { the municipal health service. I do not think so. (P7) }\end{array}$ & $\begin{array}{l}\text { No cooperation experienced } \\
\text { between the hospital and the } \\
\text { municipality }\end{array}$ & Poor coordination & \\
\hline $\begin{array}{l}\text { Right now, I am not very optimistic about my own situation, } \\
\text { because I have been to the hospital and have the problems I } \\
\text { have. I think that in time I must move to a retirement home. } \\
\text { That's probably what's going to happen. (P5) }\end{array}$ & $\begin{array}{l}\text { I am pessimistic and insecure } \\
\text { regarding my future }\end{array}$ & Insecurity & Life after discharge \\
\hline $\begin{array}{l}\text { Now I have lost my courage. I'm too slow, I'm too tired, I have no } \\
\text { strength for anything and then I get discouraged. (P10) }\end{array}$ & $\begin{array}{l}\text { I have no strength to handle } \\
\text { everyday life and it makes me } \\
\text { discouraged }\end{array}$ & $\begin{array}{l}\text { Loss of ability to manage } \\
\text { activities of daily living }\end{array}$ & \\
\hline $\begin{array}{l}\text { My family is so helpful and I my neighbor is also very kind to me. } \\
\text { She and her daughter buy groceries for me every Tuesday and } \\
\text { that's very helpful too. (P21) }\end{array}$ & $\begin{array}{l}\text { My family and my neighbor } \\
\text { help me with everyday tasks }\end{array}$ & $\begin{array}{l}\text { I could not manage } \\
\text { without their help }\end{array}$ & $\begin{array}{l}\text { Relationships with } \\
\text { next of kin }\end{array}$ \\
\hline $\begin{array}{l}\text { This is a little bit difficult for my kids to understand, you see, } \\
\text { because they are used to me being able to manage by myself. } \\
\text { They don't quite understand this new situation. Because they } \\
\text { haven't seen me so helpless before, I think. They haven't seen it. } \\
\text { So now they see me as a more helpless person. (P15) }\end{array}$ & $\begin{array}{l}\text { I am helpless and need more } \\
\text { help than before. It's hard for } \\
\text { my children }\end{array}$ & I am helpless & \\
\hline $\begin{array}{l}\text { Yes, they (the health personnel) are busy. And that very day, I } \\
\text { saw her running from one to the other. They must be tired. They } \\
\text { must be. (P20) }\end{array}$ & $\begin{array}{l}\text { The health personnel are busy } \\
\text { and do not have enough time }\end{array}$ & $\begin{array}{l}\text { The health personnel have } \\
\text { limited time to perform } \\
\text { health services }\end{array}$ & $\begin{array}{l}\text { Organizational and } \\
\text { systemic } \\
\text { determinants }\end{array}$ \\
\hline $\begin{array}{l}\text { It's not that bad now, I think. It's been worse. I usually write down } \\
\text { who's coming, because I don't always remember well. For } \\
\text { example, Friday, October 6-Then one, two, three, four, five, six, } \\
\text { seven, eight, nine different people came from the home service. } \\
\text { (P19) }\end{array}$ & $\begin{array}{l}\text { Up to nine different people } \\
\text { come each day }\end{array}$ & $\begin{array}{l}\text { Different personnel came } \\
\text { on each home visit }\end{array}$ & \\
\hline
\end{tabular}

thoughts on their situation, what mattered most to them or what challenges they would meet at home, most answered along the lines of "No, I don't think so. I can't remember them doing that" (P21).

All of the patients reported detailed biomedical examinations: "I've never been examined like that before in my whole life. It was so thorough, from head to toe. I thought it was fabulous. I have to say that I was speechless. I've never experienced such an examination before. They examined my lungs, heart, head and everything. And kidneys. It was a kidney specialist; he looked at the x-ray pictures, and there was another doctor for the lungs" (P1). The medical examination made the patients feel safe and able to trust the expertise of the health personnel, even though little effort was invested in the process of getting to know the patient or searching for a solution to the health challenges that concerned them most: "They didn't talk to me about my shingles. They were not interested in that at all. They probably didn't think it was the reason for my blood samples. They are more interested in tangible things. Things that they can investigate and take pictures of-things they can do something about" (P15). Some of these examinations even resulted in new concerns for the patients: "They were hung up on my kidney stones. I hope they don't do anything about it, because they haven't bothered me at all" (P15).

\section{Poor communication and coordination}

Although the participants were grateful for admission to hospital, most patients reported receiving scant information and too little time for preparation regarding the transition back home. As the following statements indicate, the departure came abruptly and unexpectedly to the patients: "The days went so fast. Suddenly I had to go home. I just got the notice the same day" (P20).

The patients' experiences of communication and collaboration between the hospital and the healthcare 
services in the municipality regarding their return home varied. Most reported that the healthcare services in the municipality were informed and prepared for the patients' transition, whereas others reported poor communication and failure to coordinate healthcare when they were transferred between levels of the healthcare system: "No one prepared me for leaving the hospital and returning home. And back home-no plans for anything" (P11).

Some patients in our study appealed for more information during their discharge process: "So I thought maybe I should have some papers with me? I didn't receive any information about anything. I found that strange too. I knew I was going home, but there was no information about any possible consequences of my disease, if there was something I should think about when I came back home, for instance, what to eat, and how to take medication and stuff. Nothing at all" (P19).

Several of the patients experienced a lack of clear and comprehensible information. They described how written information contained terminology "full of foreign words" (P7), with a "professional language [that was] not understandable" (P7) to them. They also experienced how the written epicrisis created insecurity and new concerns: "They gave me this huge journal, you know. It said something about me getting an ultrasound of the heart. Maybe that's what I'm going to do in September? Maybe it's heart failure? It's hard to say. No one at the hospital said anything to me about heart failure. I don't know if they examined my heart in the hospital. But maybe they did, because they took so many samples of everything, but I didn't hear anything about heart failure. Because of what's in written in the journal, I and my daughter have talked a little about the possibility that it is the heart. We talked about it, but there's nothing we can do about it anyway" (P5).

The patients in our study described being left in the dark with no opportunity to participate: "They don't ask me if it's okay, they just tell me what to do. We're not allowed to have an opinion" (P2). However, several of the patients accepted that the decision on further healthcare was taken by the healthcare personnel, because the patients felt that the health professionals know best: "It's okay that they decide. Because you are so tired. And, after all, it is the doctors' decision" (P23).

\section{Life after discharge}

After discharge, the patients described a situation characterized by uncertainty and unpredictability. They describe life as a "struggle" (P3), which they hope "will be better" (P3) in time. For some of the patients, a lack of information about unresolved health problems was the origin of the uncertainty.
This group of patients, with multiple chronic diseases and high degree of frailty, reported that their struggle was caused by loss of ability to manage the activities of daily life independently. They have neither "the strength" (P6) nor "the energy" (P20) to initiate daily activities. The patients described challenges related to house cleaning, grocery shopping and social participation. They narrated how they struggled to participate in meaningful activities, primarily owing to their physical condition: "Previously I had guests all the time, but I don't have the same capacity anymore. I have realized that. I just hope I can get a little bit better. I can't do things the way I did before. It is no use. It has gone steeply downwards with my social life" (P15). A more isolated social life led to loneliness, depression and a feeling of despair and nothing to live for: "I have missed out on so many beautiful days this summer. I am so tired of this life. In two years, I will be one hundred. I certainly don't want to get that old. Especially when I have become as disabled as I am now" (P7).

Most of the patients strove to maintain their independence and master everyday tasks. They had to rely on help from relatives and healthcare professionals to manage life at home. They described the situation using words such as "helplessness" (P13), "desperation" (P13), "concern" (P6) and "fear" (P7). Because of the challenges they encountered at home, and the insecurity and uncertainty that characterizes their situation, the thought of "giving up" (P19) had crossed their minds.

\section{Relationships with next of kin}

An informal caregiver, ranging from a spouse to an adult child/grandchild, niece, friend or neighbor, usually assisted the patients with needs beyond those that the health services could support. The patients describe the help as a necessary resource to cover practical needs. Almost all of the participants in this study received regular help with grocery shopping from family or neighbors. Laundry, house cleaning, transportation and paying bills are other examples of needs covered by the participant's next of kin. The patients expressed the view that they would not be able to manage everyday life without help from their caregivers. Quotes such as " $M y$ son organizes everything for me" (P9) and "I don't understand how I could manage without their help" (P23) illustrate how dependent they are on this help. They also describe how relatives act as a safety net in the time after hospitalization, and the patients trust that their next of kin will take appropriate action if they become sicker or if the home situation becomes "unsafe" (P20).

The patients emphasize positive and strong relations with their next of kin as an important factor in managing life after discharge. However, they worried that their illness would put a strain on these relationships. 
The patients were aware that informal caregivers had "limited time owing to other commitments" (P10). Several of the patients reported feeling like a burden on their closest relatives in the period after hospitalization: "I' $m$ just a burden to everyone around me. Everyone has to take care of me. It doesn't feel good. I've always been able to manage by myself" (P13). This concern resulted in feelings of stress, anxiety and guilt.

\section{Organizational and systemic determinants}

Many of the patients reported that the workload and time pressure on health personnel affected the healthcare they received. The patients blamed the system rather than the staff, and they accepted that health professionals performed their clinical work while balancing patient needs, available resources and regulatory constraints. The participants found that the healthcare personnel in the hospital and in the municipality had limitations: "They are probably doing their best. But they're always in a hurry. It is quite clear. They are so frantic, rushing from one person to another. So they take advantage of the staff" (P2).

Four of the 18 patients were transferred to intermediate care units before returning to their own homes. These patients found the healthcare staff in intermediate care to be stressed, distant or in a hurry, with "little time to speak with me" (P1). They also reported that the professionals in intermediate care wards had little ability to offer individualized care to patients, owing to limited resources: "The days get long in here. The nights as well. I wake up very early, usually at half past five or six. But I have to stay in my bed until 8.30 or 9 am. They don't have time before that. They don't start work so early, either. So I rarely get out of bed before nine. They are very busy" (P2).

Most of the patients receiving healthcare services from the municipality reported short visits. These allowed little time for conversation or discussions of matters of concern to the patients. The patients also found that different personnel came on each visit, and several reported extensive use of temporary workers: "There are different people (from the homecare service) each time. It's never the same person" (P5).

Several of the patients commented that their general practitioner was very busy, with too little time for them. They described visits with a biomedical focus, where the patient's own thoughts about his/her illness were not a theme; nor was how the disease had affected the patient's daily life. The following quotes illustrate patients' experiences of meetings with their general practitioner.

I noticed (that the GP was in a hurry), because she started talking about other things, getting up and moving towards the door, because she was 1 hour late. I was about to ask about other things, but then I didn't do that. (P6).

The GPs have a lot to do, are in a hurry. They don't have time for the patient. They have to write things and look at the screen with no attention given to the patient. But that's how it is. They probably have around 15 min per patient. (P15).

\section{Discussion}

The results of this study indicate that elderly people receiving healthcare in hospitals and in the municipality face several challenges regarding the quality of services. The elderly patients reported few invitations to participate in decisions regarding their own care, to share their concerns or to tell staff members what was important to them. They reported insecurity and distress owing to a lack of information and coordination between the levels of the healthcare system. They described limitations in their capacity that made daily tasks challenging and prevented them from participating socially. The caregivers helped patients with practical needs when the health service was unable to assist owing to organizational and systemic determinants. They received the needed help with gratitude, but also described a loss of autonomy, helplessness and a fear of being a burden to everyone. The patients experienced healthcare services that focused on their diagnosis rather than listening to their concerns or addressing their need for practical assistance and social participation.

The discussion below is organized according to the main factors in the WHO's strategy for quality improvement. The WHO describes quality healthcare as services that are effective, efficient, integrated, patient centered, equitable and safe [8].

For effective care, the WHO states that the service should provide evidence-based care to those who need it [8]. The elderly patients in our study experienced a health service that seemed to be based on measurable values. The thorough biomedical examination and the focus on revealing a diagnosis and defects in the elderly patients may be an expression of a desire to ensure that the services are consistent with knowledge about and evidence for achieving the best possible outcomes for the patients [3]. The biomedical model of the past century has been valuable for some aspects of medicine, and is a necessary but not sufficient component in the proper care of patients [44]. Modern medicine has successfully applied biomedical science through a model that defines disease as the disruption or deviation of biological variables. This focus on deviations from biological norms can lead to the neglect of patients' needs, and the medical examination is seen as an intrinsic good 
in itself rather than as a means to help individuals achieve goals that are important to them [44]. This is in line with the patients' experiences; few reported being asked about their goals or what mattered to them. Failure to honor the patients' goals can result in the overuse of disease-focused treatments at the end of life [44]. The patients in our study reported that detailed examinations resulted in new diagnoses, which led to further medical investigations. On the other hand, the thorough medical examination made the patients feel safe and made them trust the competence of health personnel. Delivering safe services is one of the main components of quality healthcare [8].

In addition to the health services being effective and safe, according to the WHO, they must also be patient centered [8]. Patient centeredness represents a cultural shift in healthcare [45] from the biomedical model, in which the patient is a passive target of the healthcare system, to a model where the patient is an active partner in his/her care and decision-making [45, 46]. As indicated above, the patients interviewed did not experience this shift. Instead, they reported that the services were concerned about examining them, diagnosing them and treating their diseases. Few patients in this study were included in clinical decisions regarding their own health. Some of our participants even reported that they were not asked or allowed to have an opinion about their own healthcare. Despite decades of attention to principles of activating, empowering and engaging the patients in their own healthcare $[9,47-49]$ as part of securing patient centeredness as a cornerstone of healthcare service quality $[48,50]$, the service did not appear to be responsive to older patients' preferences or needs.

Patient centeredness and patient-centered care often assumes that all patients have the competence and ability to participate in important decisions about their own care [51]. The frameworks for participation are often characterized by efficiency requirements, so patient groups with reduced physical and cognitive abilities may have limited opportunities to participate [52, 53]. Our patients reported reduced capacity with little capability to engage in daily tasks and decisions concerning their own health. The decision-making capacity of older patients may be limited owing to cognitive decline, emotional distress, multiple chronic conditions or a combination of these [54]. Shared decision-making with older patients who are frail requires a continuous counselling dialogue [55] adapted to each patient's capacity. Equitable care for this patient group means that elderly people have the same rights to healthcare as everyone else [8], but it also means that healthcare authorities and personnel have an obligation to make particular efforts to secure healthcare attuned to older patients' needs and preferences [3]. Our results confirm the findings of other studies that older adults with multiple chronic conditions receive care that is fragmented and seldom focused on what matters most to the patient [56].

Current policies in the Western world emphasize that good quality in healthcare is related to older people living in their own homes. It is also documented that most older people prefer to age in their own home $[57,58]$. Consistent with this, the overall aim of home care services is to assist older people to live independently in their homes and maintain quality of life for as long as possible [59]. However, our findings indicate that the elderly patients experienced significant problems in maintaining quality of life and independence after discharge. Multimorbid or frail patients may require services that are not frequently considered part of the clinical routine (e.g., support at home for daily activities and transportation) but are crucial for the success of clinical interventions for this patient group [60]. According to the patients, the gap between their need for assistance to cope with everyday life after discharge and the help provided by the services in the municipality had to be filled by family and relatives. This finding agrees with previous research, which highlights that to rationalize limited resources, relatives are important but often invisible contributors to elderly patient care [61, 62]. In line with previous research, the patients in this study also relied on family and informal caregivers for their social needs [63, 64]. Being dependent on help from caregivers and friends was a concern for the patients. They reported that dependence led to concerns about being a burden on their loved ones. Other studies showed similar results, describing older patients worrying about burdening their families because of practical matters such as time and resources [65]. For our participants, being a burden to others was associated with stress and anxiety. Some studies showed that for patients, the sense of being a burden is related to depression, distress and reduction in life quality [66, 67]. By not receiving equitable care adapted to their health conditions and their needs, the patients in this study were left in limbo, struggling to find a balance in their everyday life.

Providing efficient services means that the resources are allocated and used in the best possible manner to achieve desired outcomes [8]. The patients encountered healthcare personnel with limited time. Most of the patients receiving healthcare services from the municipality reported short visits with little time for conversation or discussions of what mattered to the patient. The patients blamed the system rather than the staff, and they accepted that health professionals in their clinical work balanced the patient's needs against available resources and regulatory constraints. Health personnel are often constrained by the goals, requirements and limitations imposed by organizational and systemic determinants, 
and they must find ways to resolve the possible incompatibility between patient-centered goals and organizational goals $[68,69]$. Thus, the healthcare quality experienced by older patients is limited by organizational constraints and the dilemmas that health professionals must address in their work. As people with multimorbidity face multiple health and/or social problems, it is especially important to offer a patientcentered integrated care approach that is tailored to the individual and his/her environment. The situation of people with multimorbidity may change over time, so flexibility is important-flexible care can be continuously updated to match a person's needs [70]. Based on the patients' experiences, it appears that healthcare services, owing to organizational determinants, fail to deliver flexible patient-centered healthcare attuned to issues of significance to elderly patients. Research has shown that individualized patient-centered interactions promote adherence to treatment and lead to improved health outcomes [71]. By receiving personalized services, the patients may increase their capacity and live independent lives in own homes at reduced cost of help and care.

Quality of healthcare means providing care that is integrated and coordinated across levels [8]. For this group of patients, quality of healthcare services depends greatly on good planning to provide a safe journey through the healthcare system and reduce readmissions to hospitals $[70,72]$. This process includes effective collaboration and communication between patients, their carers/next of kin and health professionals when moving across care settings [17, 73]. As mentioned above, elderly patients are being discharged from hospital "quicker and sicker" than before $[5,6,74]$, leaving the healthcare provider with limited time to coordinate services across settings [7]. Poor communication and suboptimal care coordination [72] across healthcare providers and settings produce more frequent hospital readmissions and poor quality outcomes [75]. Despite focus in recent years on improving the coordination of care across care settings, our findings show that communication across care settings still needs improvement. Lack of integration between the levels in the healthcare system left the patients feeling unsafe and insecure and caused them concern about their future health.

\section{Strengths and limitations}

As in other qualitative research, the goal of this study was to enhance our understanding of the phenomenon being studied [26]. We aimed to give a voice to older patients about their experiences of the quality of healthcare services. However, the study is limited by the specific demographics of the small sample size and the geographical location. Even though the findings in this study cannot be generalized, the results may be transferred to similar situations or people [26].

The authors of this study have backgrounds in nutrition, nursing and physiotherapy, in addition to clinical practice, leadership, quality improvement and professional development in the health services. Throughout the study, we were conscious that our previous understanding and backgrounds would influence the research process [29]. We strove to interpret the data openly and to provide a transparent description of the path from the data to the results. The involvement of multiple researchers from different backgrounds may strengthen the design of a study, as they can supplement and contest each other's statements [76].

The patients' vulnerable situations and poor health may have influenced the quality of the interviews. The interviewer did her best to put the participants at ease and to listen empathetically and carefully, and several patients expressed their appreciation of the opportunity to tell their story. By conducting a follow-up interview, we were able to grasp the situations and experiences throughout the 30-day period. This may be a strength of the study.

\section{Conclusion}

To deliver healthcare quality, all of WHO's six dimensions (effectiveness, efficiency, integration, patient centeredness, equitableness, safety) must be present. The elderly patients' stories shows us that these dimensions are not always present. Instead of focusing on the special needs of elderly patients with multimorbidity, the healthcare services were attuned to measurable values and biomedical inquiries. Few possibilities for participation, scant information and suboptimal care coordination left the patients with a feeling of being in limbo, where they struggled to find balance in their everyday life.

This study in line with other research, shows that further work must be done to ensure coverage of integrated services without a financial burden, centered on the needs and rights of older people [54]. Healthcare quality for elderly people demands a healthcare system organized in ways that ensure care and support consistent with their basic rights, fundamental freedoms and human dignity.

\section{Relevance to clinical practice}

Elderly people have a right to make choices and take control over a range of issues including their own healthcare. The possibilities for choice and control are shaped by many factors, including the intrinsic capacity of the older people, the environments they inhabit, the personal and financial resources they can draw on, and the opportunities available to them. Together these determine the autonomy of older people, which has been shown to have a powerful influence on their dignity, 
integrity, freedom and independence, and has been repeatedly identified as a core component of their general well-being.

To deliver effective, efficient and integrated healthcare to older patients, the service needs to be perceived as patient centered, equitable and safe by the patients themselves.

To achieve this, the healthcare services must:

- shift their focus from disease to intrinsic capacity

- be organized in ways that secure person-centered and integrated care for older people

- ensure there are highly qualified personnel with expertise in the needs and challenges that older patients with multimorbidity face in healthcare and in daily life.

\section{Supplementary information}

Supplementary information accompanies this paper at https://doi.org/10. 1186/s12913-020-05303-5.

Additional file 1: COREQ checklist.

\section{Acknowledgements}

Not applicable.

\begin{abstract}
Authors' contributions
IL preformed the interviews and was a major contributor in writing the manuscript. All the authors (IL, JD, AB1, AB2) read the transcribed material searching for meaning and patterns. Reiterative reading of the transcripts was performed by two of the authors (IL and AB1) to identify the interesting features of the data. These initial codes were then categorized into potential themes. The themes were discussed and reviewed by all authors (IL, JD, AB1, $A B 2$ ) to reflect on their relevance to the research questions. All authors read and approved the final manuscript.
\end{abstract}

\section{Funding}

The project was funded by The Research Council of Norway and is part of a larger project of Crosscare-old (project.nr. 256644/H10). The funding body had no role in the design of the study and collection, analysis, and interpretation of data and in writing the manuscript.

\section{Availability of data and materials}

The datasets generated and/or analysed during the current study are not publicly available due to privacy concerns but are available from the corresponding author on reasonable request.

\section{Ethics approval and consent to participate}

The study was preapproved and registered by the Norwegian Center for Research Data (No. 53110). All of the patients were deemed able to give informed consent by healthcare personnel in hospital. The first author approached the participants in hospital, and provided them with verbal and written information outlining the purpose of the study. We informed them that participation was voluntary and about their right to withdraw from the study at any stage. We assured them that this would not affect their current or future access to services. We obtained written and informed consent from all participants and guaranteed their confidentiality.

\section{Consent for publication}

Not Applicable.

\section{Competing interests}

The authors declare that they have no competing interests.

\section{Author details}

'Department of Physiotherapy, Faculty of Health Sciences, Oslo Metropolitan University, Oslo, Norway. ${ }^{2}$ Department of Nursing and Health Promotion, Faculty of Health Sciences, Oslo Metropolitan University, Oslo, Norway. ${ }^{3}$ European Palliative Care Research Centre (PRC), Department of Oncology, Oslo University Hospital and Institute of Clinical Medicine, University of Oslo, Oslo, Norway. ${ }^{4}$ Department of Physiotherapy, Faculty of Health Sciences, Oslo Metropolitan University, Oslo, Norway.

Received: 21 June 2019 Accepted: 6 May 2020

Published online: 20 May 2020

\section{References}

1. UN. Aging https://www.un.org/en/sections/issues-depth/ageing/ (2017). Accessed 16 Apr 2019

2. Kingston A, Robinson L, Booth H, Knapp M, Jagger C. Projections of multimorbidity in the older population in England to 2035: estimates from the population ageing and care simulation (PACSim) model. Age Ageing. 2018; 47(3):374-80.

3. WHO: World report on aging and health. https://www.who.int/ageing/ publications/world-report-2015/en/ (2015). Accessed 16 Apr 2019.

4. OECD/EU, Health at a Glance: Europe 2018: State of health in the EU cycle, OECD Publishing, Paris/EU, Brussels, https://doi.org/10.1787/health_glance_ eur-2018-en. Accessed 16 Apr 2019

5. Galvin EC, Wills T, Coffey A. Readiness for hospital discharge: a concept analysis. J Adv Nurs. 2017;73(11):2547-57.

6. Deniger A, Troller P, Kennelty KA. Geriatric transitional care and readmissions review. J Nurse Pract. 2015;11(2):248-52.

7. Suwan N, Panuthai S, Lasuka D, Khampolsiri T. Factors influencing readiness for hospital discharge among Thai older persons with chronic obstructive pulmonary disease. Pacific Rim Int J Nurs Res. 2018;22(2):156-68.

8. WHO: Handbook for national quality policy and strategy - A practical approach for developing policy and strategy to improve quality of care. https://www.who.int/servicedeliverysafety/areas/ghc/nqps_handbook/en/ (2018). Accessed 16 Apr 2019.

9. Batalden P. Getting more health from healthcare: quality improvement must acknowledge patient coproduction —an essay by Paul Batalden. In.: British Medical Journal Publishing Group; 2018.

10. Nadi A, Shojaee J, Abedi G, Siamian H, Abedini E, Rostami F. Patients' expectations and perceptions of service quality in the selected hospitals. Med Arch. 2016;70(2):135.

11. Castro EM, Van Regenmortel T, Vanhaecht K, Sermeus W, Van Hecke A. Patient empowerment, patient participation and patient-centeredness in hospital care: a concept analysis based on a literature review. Patient Educ Couns. 2016;99(12):1923-39.

12. Dyrstad DN, Laugaland KA, MJJocn S. An observational study of older patients' participation in hospital admission and discharge-exploring patient and next of kin perspectives. J Clin Nurs. 2015;24(11-12):1693-706.

13. Hall AM, Ferreira PH, Maher CG, Latimer J, Ferreira ML. The influence of the therapist-patient relationship on treatment outcome in physical rehabilitation: a systematic review. J Phys Ther. 2010;90(8):1099-110.

14. Steihaug S, Johannessen A-K, Ådnanes M, Paulsen B, Mannion R. Challenges in achieving collaboration in clinical practice: the case of Norwegian health care. Int J Integr Care. 2016;16:3.

15. Naylor MD, Feldman PH, Keating S, Koren MJ, Kurtzman ET, Maccoy MC. Krakauer RJJoEiCP: Translating research into practice: transitional care for older adults. J Eval Clin Pract. 2009;15(6):1164-70.

16. HMJNEJOM K. Post-hospital syndrome-an acquired, transient condition of generalized risk. N Engl J Med. 2013;368(2):100-2.

17. Storm M, Siemsen IMD, Laugaland K, Dyrstad DN, Aase K. Quality in transitional care of the elderly: key challenges and relevant improvement measures. Int J Integr Care. 2014;14:e013.

18. Lanièce I, Couturier P, Dramé M, Gavazzi G, Lehman S, Jolly D, Voisin T, Lang $\mathrm{PO}$, Jovenin N, Gauvain JBJA, et al. Incidence and main factors associated with early unplanned hospital readmission among French medical inpatients aged 75 and over admitted through emergency units. Age Ageing. 2008;37(4):416-22.

19. Gusmano M, Rodwin V, Weisz D, Cottenet J, CJJohsr Q. policy: Comparison of rehospitalization rates in France and the United States. J Health Serv Res Policy. 2015;20(1):18-25. 
20. Lum HD, Studenski SA, Degenholtz HB, SEJJogim H. Early hospital readmission is a predictor of one-year mortality in community-dwelling older Medicare beneficiaries. J Gen Intern Med. 2012;27(11):1467-74.

21. Dramé M, Lang P, Novella J-L, Narbey D, Mahmoudi R, Laniece I, Somme D, Gauvain J-B, Heitz D, TJRdeedsp V. Six-month outcome of elderly people hospitalized via the emergency department: the SAFES cohort. Rev Epidemiol Sante Publique. 2012;60(3):189-96.

22. Jencks SF, Williams MV, EAJNEJoM C. Rehospitalizations among patients in the Medicare fee-for-service program. N Engl J Med. 2009;360(14):1418-28.

23. Carey K, M-YJHA L. Readmissions to New York hospitals fell for three target conditions from 2008 to 2012, consistent with Medicare goals. Health Aff (Millwood). 2015;34(6):978-85.

24. Noest S, Ludt S, Klingenberg A, Glassen K, Heiss F, Ose D, Rochon J, Bozorgmehr K, Wensing M, Szecsenyi J. Involving patients in detecting quality gaps in a fragmented healthcare system: development of a questionnaire for Patients' experiences across health care sectors (PEACS). Int J Qual Health Care. 2014;26(3):240-9.

25. CROSSCARE-OLD. https://blogg.hioa.no/crosscareold. Accessed 16 Apr 2019.

26. Malterud K. Qualitative research: standards, challenges, and guidelines. Lancet. 2001;358(9280):483-8.

27. The Norwegian Health Care System. https://international. commonwealthfund.org/countries/norway/. Accessed 16 Apr 2019.

28. Holm S, Mathisen T, Saeterstrand T, Brinchmann B. Allocation of home care services by municipalities in Norway: a document analysis. BMC Health Serv Res. 2017:17:673.

29. Creswell JW, Poth CN. Qualitative inquiry \& research design : choosing among five approaches, fourth edition. Edn. SAGE: Los Angeles; 2018.

30. Baztan JJ, Suarez-Garcia FM, Lopez-Arrieta J, Rodriguez-Manas L, RodriguezArtalejo $F$. Effectiveness of acute geriatric units on functional decline, living at home, and case fatality among older patients admitted to hospital for acute medical disorders: meta-analysis.(Report). Br Med J. 2009;338(7690):334.

31. Jones CJ, Rikli RE, Beam WC. A 30-s chair-stand test as a measure of lower body strength in community-residing older adults. Res Q Exerc Sport. 1999; 70(2):113-9.

32. Millor N, Lecumberri P, Gomez M, Martinez-Ramirez A, Izquierdo M. An evaluation of the 30-s chair stand test in older adults: frailty detection based on kinematic parameters from a single inertial unit.(Report). J Neuroeng Rehabil. 2013;10:1.

33. Dumurgier J, Elbaz A, Ducimetiere P, Tavemier B, Alperovitch A, Tzourio C. Slow walking speed and cardiovascular death in well functioning older adults: prospective cohort study. Br Med J. 2009;339(7731):1187.

34. Tombaugh TN, NJJJotAGS MI. The mini-mental state examination: a comprehensive review. J Am Geriatr Soc. 1992;40(9):922-35.

35. Crouch $M, M c K e n z i e ~ H$. The logic of small samples in interview-based qualitative research. Soc Sci Inf. 2006:45(4):483-99.

36. Braun V, Clarke V. Using thematic analysis in psychology. Qual Res Psychol. 2006:3(2):77-101.

37. Holloway I, Todres L. The status of method: flexibility, consistency and coherence. Qual Res. 2003;3(3):345-57.

38. Creswell JW, Creswell JD. Research design : qualitative, quantitative \& mixed methods approaches, 5th edition. Edn. Los Angeles, California: Sage; 2018.

39. Braun V, Clarke V. What can "thematic analysis" offer health and wellbeing researchers? Int J Qual Stud Health Well-being. 2014;9(1):26152.

40. Lincoln YS, Guba EG. Naturalistic inquiry. Beverly Hills, Calif: Sage; 1985.

41. Bryman A. Social research methods, 5th ed. edn. Oxford: Oxford University Press; 2016.

42. Patton MQ. Qualitative research \& evaluation methods : integrating theory and practice, 4th ed. edn. Los Angeles, Calif: Sage; 2015.

43. Tong A, Sainsbury P, Craig J. Consolidated criteria for reporting qualitative research (COREQ): a 32-item checklist for interviews and focus groups. Int Qual Health Care. 2007:19(6):349-57.

44. Saini V, Garcia-Armesto S, Klemperer D, Paris V, Elshaug AG, Brownlee S, loannidis JPA, Fisher ES. Drivers of poor medical care. Lancet. 2017; 390(10090):178-90

45. Eklund JH, Holmström IK, Kumlin T, Kaminsky E, Skoglund K, Höglander J, Sundler AJ, Condén E. Meranius MSJPe, counseling: "same same or different?" a review of reviews of person-centered and patient-centered care; 2018.

46. Holmström I, Röing M. The relation between patient-centeredness and patient empowerment: a discussion on concepts. Patient Educ Couns. 2010; 79(2):167-72.
47. Levenstein $\mathrm{JH}$, McCracken EC, McWhinney IR, Stewart MA, BROWN JB. The patient-centred clinical method. 1. A model for the doctor-patient interaction in family medicine. Fam Pract. 1986;3(1):24-30.

48. Eklund JH, Holmström IK, Kumlin T, Kaminsky E, Skoglund K, Höglander J, Sundler AJ, Condén E. Meranius MS: "same same or different?" a review of reviews of person-centered and patient-centered care. Patient Educ Couns. 2019;102(11):3-11.

49. Batalden PB, Davidoff F. What is "quality improvement" and how can it transform healthcare? In: BMJ Publishing Group Ltd; 2007.

50. Stockdale SE, Zuchowski J, Rubenstein LV, Sapir N, Yano EM, Altman L, Fickel $\mathrm{J}$. Fostering evidence-based quality improvement for patient-centered medical homes: initiating local quality councils to transform primary care. (report)(author abstract). Health Care Manag Rev. 2018;43(2):168-80.

51. Dent M, Pahor M. Patient involvement in Europe - a comparative framework. J Health Org Manag. 2015;29(5):546-55.

52. Christensen M, Fluge S. Brukermedvirkning i norsk eldreomsorgspolitikk Om utviklingen av retorikken om individuelt ansvar. In: Tidsskrift for velferdsforskning vol, vol. 3; 2016. p. 261-77.

53. Vabø M. Organisering for velferd: hjemmetjenesten i en styringsideologisk brytningstid. Oslo: Norsk institutt for forskning om oppvekst, velferd og aldring; 2007.

54. Hughes JM, Freiermuth CE, Shepherd-Banigan M, Ragsdale L, Eucker SA, Goldstein K, Hastings SN, Rodriguez RL, Fulton J, Ramos K, et al. Emergency department interventions for older adults: a systematic review. J Am Geriatr Soc. 2019;67(7):1516-25

55. Van De Pol MHJ, Fluit CRMG, Lagro J, Slaats Y, Olde Rikkert MGM, LagroJanssen ALM. Shared decision making with frail older patients: proposed teaching framework and practice recommendations. Gerontol Geriatr Educ. 2017;38(4):482-95.

56. Blaum CS, Rosen J, Naik AD, Smith CD, Dindo L, Vo L, Hernandez-Bigos K, Esterson J, Geda M, Ferris R. Feasibility of implementing patient priorities Care for Older Adults with multiple chronic conditions. J Am Geriatr Soc. 2018;66(10):2009-16.

57. Berglund H, Duner A, Blomberg S, Kjellgren K. Care planning at home: a way to increase the influence of older people? Int J Integr Care. 2012;12.

58. Perry TE. Moving as a gift: relocation in older adulthood. J Aging Stud. 2014:31:1-9.

59. Beard JR, Officer A, de Carvalho IA, Sadana R, Pot AM, Michel J-P, LloydSherlock P, Epping-Jordan JE, Peeters GG, WRJTL M. The World report on ageing and health: a policy framework for healthy ageing. Lancet. 2016; 387(10033):2145-54

60. Onder G, Cesari M, Maggio M, Palmer K. Defining a care pathway for patients with multimorbidity or frailty. Eur J Intern Med. 2017;38:1-2.

61. Tønnessen S, Nortvedt P, RJNe F. Rationing home-based nursing care: professional ethical implications. Nurs Ethics. 2011;18(3):386-96.

62. Strøm A, Andersen KL, Korneliussen K, MSJJomh F. Being "on the alert" and "a forced volunteer": a qualitative study of the invisible care provided by the next of kin of patients with chronic heart failure. J Multidiscip Healthc. 2015;8:271.

63. Schoot T, Proot I, Meulen RT, LJCNR DW. Actual interaction and client centeredness in home care. Clin Nurs Res. 2005;14(4):370-93.

64. Hawley HJHEJ: Older adults' perspectives on home exercise after falls rehabilitation: Understanding the importance of promoting healthy, active ageing. 2009, 68(3):207-218.

65. Hafskjold L, Eide T, Holmström IK, Sundling V, Sv D, Eide H. Older persons' worries expressed during home care visits: exploring the content of cues and concerns identified by the Verona coding definitions of emotional sequences. Patient Educ Couns. 2016.

66. Kuo SC, Chou WC, Hou MM, Wu CE, Shen WC, Wen FH, STJEjocc T. Changes in and modifiable patient-and family caregiver-related factors associated with cancer patients' high self-perceived burden to others at the end of life: A longitudinal study. Eur J Cancer Care (Engl). 2018;27(6):e12942.

67. McPherson CJ, Wilson KG, Leclerc C, Chyurlia L, Elliott TR. The balance of give and take in caregiver-partner relationships: an examination of self-perceived burden, relationship equity, and quality of life from the perspective of care recipients following stroke. Rehabil Psychol. 2010;55(2):194-203.

68. Lipsky M. Street-level bureaucracy : dilemmas of the individual in public services, 30th anniversary expanded ed. edn. New York: Russell Sage Foundation; 2010 ,

69. Alper BS, Elwyn G, Price A. Prioritizing shared decision making. JAMA. 2017; 317:856-7.

70. Leiiten FRM, Struckmann V, van Ginneken E, Czypionka T, Kraus M, Reiss M, Tsiachristas A, Boland M, de Bont A, Bal R, et al. The SELFIE framework for 
integrated care for multi-morbidity: development and description. Health Policy. 2018;122(1):12-22.

71. Robinson JH, Callister LC, Berry JA, Dearing KA. Patient-centered care and adherence: Definitions and applications to improve outcomes, vol. 20. Malden; 2008. p. 600-7.

72. Watts $\mathrm{R}$, Gardner $\mathrm{H}$, Pierson J. Factors that enhance or impede critical care nurses' discharge planning practices. Intensive Crit Care Nurs. 2005;21(5):302-13.

73. Heidi G, Astri S. Earlier hospital discharge: a challenge for Norwegian municipalities. Nordic J Soc Res. 2017;8.

74. Spehar AM, Campbell RR, Cherrie C, Palacios P, Scott D, Baker JL, Bornstad B, Wolfson J. Agency For Healthcare R, Quality Rockville MD: Seamless Care: Safe Patient Transitions From Hospital to Home; 2005.

75. Dusek B, Pearce N, Harripaul A, Lloyd M. Care transitions: a systematic review of best practices. J Nurs Care Qual. 2015;30(3):233-9.

76. Gale NK, Heath G, Cameron E, Rashid S, Redwood S. Using the framework method for the analysis of qualitative data in multi-disciplinary health research. BMC Med Res Methodol. 2013;13:117.

\section{Publisher's Note}

Springer Nature remains neutral with regard to jurisdictional claims in published maps and institutional affiliations.

Ready to submit your research? Choose BMC and benefit from:

- fast, convenient online submission

- thorough peer review by experienced researchers in your field

- rapid publication on acceptance

- support for research data, including large and complex data types

- gold Open Access which fosters wider collaboration and increased citations

- maximum visibility for your research: over $100 \mathrm{M}$ website views per year

At $\mathrm{BMC}$, research is always in progress.

Learn more biomedcentral.com/submissions 